\title{
Oral Diagnosis
}

\section{Oral Mucositis in Children Suffering from Acute Lymphoblastic Leukaemia \\ Sahar H. Alani}

Ass.Prof ,B.D.S ,Ms.C.(oral \& maxillofacial radiology),Ph.D.(oral patho.),Oral Diagnosis Depart.,College of Dentistry-University of Baghdad.

Ghufran A. Hasan

Ass.Lecturer,B.D.S,Ms.C. Oral Diagnosis Depart.,College of Dentistry-University of Baghdad. Sajid m. Hameed

Bsc.(nursing), Ministry of Health in Iraq

\section{ABSTRACT}

Background: Oral mucositis is the most commonly reported side effect observed in neoplastic patients treated with chemotherapy and radiotherapy of the head and neck region as well as in patients who have received a haematopoietic stem cell transplant. The aim of the study was to assess the oral mucosa status in children with acute lymphoblastic leukaemia (ALL) during antineoplastic therapy.

Material and methods: The clinical examination included 127 children aged 5-15 with ALL. The clinical examination was conducted using the dental diagnostic instrument. The condition of the oral mucosa was determined using the WHO scale for oral mucositis.

Results: In the first period of antineoplastic therapy the pathological lesions of the oral mucosa of the mucositis type were observed among the examined patients. The lesions had various levels of intensity. Pain was found to be the primary symptom of oral mucositis. In this study the following were observed: local erythema of the oral mucosa in $10 \%$, ulcerative lesions in $5 \%$.The remaining $85 \%$ patient who could not eat or drink because of pain and soreness.

Conclusion: Local treatment of oral mucositis with polyantibiotic-antifungal mixture, supporting antifungal systemic treatment, and improving the overall peripheral blood conditions in children suffering from acute lymphoblastic leukaemia improve the condition of the oral mucosa.

Key words: oral mucositis, acute lymphoblastic leukaemia (ALL).

\section{INTRODUCTION}

Pathological changes of the oral mucosa defined as oral mucositis are caused by cytotoxic effects of chemotherapy and local radiotherapy of the head and neck region. Oral mucositis symptoms are also observed in $40-100 \%$ of patients who have had stern cell transplantation. Oral inflammation caused by stomatotoxic chemotherapy is painful and restricts oral administration of drugs, also increasing the risk of infection of the intrinsic oral cavity flora. It is a serious problem, which results in decreased doses of administered drugs and may increase the cost of tumor treatment. General incidence of mucositis may differ and depends on the diagnosis and the patient's age, previous condition of the oral cavity, as well as the type, dose and frequency of administration of pharmacological medicines. WHO distinguishes five grades of oral mucositis severity (Table 1):

Table 1: WHO Classification of oral mucositis

\begin{tabular}{|c|c|}
\hline Grade & Symtoms \\
\hline 0 & no symptoms of oral mucositis \\
\hline 1 & redness, erythema, soreness \\
\hline 2 & $\begin{array}{l}\text { erythema and ulceration, patient can swal- } \\
\text { low solid food }\end{array}$ \\
\hline 3 & $\begin{array}{c}\text { ulceration and erythema, patient can- } \\
\text { not swallow solid food }\end{array}$ \\
\hline 4 & $\begin{array}{l}\text { ulceration and pseudomembrane } \\
\text { formation of such severity that } \\
\text { alimentation is not possible }\end{array}$ \\
\hline
\end{tabular}

Development of oral cavity inflammation defined as mucositis is claimed to be a complex pathological process, in which proinflammatory cytokines play an essential role. In a five-phase model of mucositis pathogenesis, the primary cause and trigger of the inflammatory process, is microvascular injury to quickly dividing basal epithelial cells during radiation and chemotherapy, which results in production and release of free oxygen radicals, which in turn activates cytokines, including tumor necrosis factor-alpha, produced mainly by macrophages and interleukin-1 and -6. Developing ulcers in the mucosa are a base for development of bacterial microflora leading to secondary infections. The fifth and last phase is healing, which is characterised by epithelial cell proliferation, tissue differentiation and recovery of epithelial integrity ${ }^{(1,2)}$.

Among patients treated according to the protocol for high risk patients, severe mucositis occurs in more than $60 \%$. Half of those patients experience deterioration of the oral mucosa condition, which is so serious that it requires changes in the antitumor treatment and/or administration of parenteral analgesia. Observations reveal that oral mucositis occurs more often in children than in adults with a similar tumor disease. Oral inflammation is also more often observed in patients after bone morrow transplantation $(2,3,4)$

\section{AIM OF THE STUDY}

The aim of the study was to assess oral mucosa 
in children suffering from acute lymphoblastic leukaemia during anti-tumor treatment.

\section{MATERIAL AND METHODS}

The study included 127 children aged from 5 to 15 suffering from acute lymphoblastic leukaemia (ALL) (Table2). All patients diagnosed by physicians (Table 3).

Table 2: Age and, gender distribution for (127) patients with ALL

\begin{tabular}{|l|c|c|c|c|c|c|}
\hline \multirow{2}{*}{ Age } & \multirow{2}{*}{$\boldsymbol{F}$} & \multirow{2}{*}{$\%$} & \multicolumn{2}{|c|}{ Males } & \multicolumn{2}{c|}{ Females } \\
\hline $\mathbf{5 - 7}$ & 20 & 16 & 10 & 8 & 10 & 8 \\
\hline $\mathbf{8 - 9}$ & 55 & 43 & 35 & 27 & 20 & 16 \\
\hline $\mathbf{1 0 - 1 2}$ & 30 & 24 & 18 & 14 & 12 & 9 \\
\hline $\mathbf{1 3 - 1 5}$ & 22 & 17 & 12 & 9 & 10 & 8 \\
\hline Total & 127 & 100 & 75 & 58 & 52 & 32 \\
\hline
\end{tabular}

Tabie 3: Methods of diagnosis for (127) patients with ALL

\begin{tabular}{|l|c|c|}
\hline \multicolumn{1}{|c|}{ Categories } & $\boldsymbol{F}$ & $\%$ \\
\hline Core biopsy lymph node & 40 & 31 \\
\hline Blood tests & 20 & 16 \\
\hline Biochemical tests & 15 & 12 \\
\hline Ultra sound abdomen & 12 & 9 \\
\hline Bone marrow biopsy & 40 & 31 \\
\hline Total & 127 & 100 \\
\hline
\end{tabular}

The study group collected from different areas in Iraq (Table 4).

Table 4 : Residence for (127) patients and place of hospital with ALL

\begin{tabular}{|l|c|c|c|c|c|c|}
\hline \multirow{2}{*}{ Categories } & \multirow{2}{*}{$\boldsymbol{F}$} & \multirow{2}{*}{$\%$} & \multicolumn{4}{|c|}{ Hospitals } \\
\cline { 3 - 8 } & & & \multicolumn{2}{|c|}{ W.T.H $*$} & \multicolumn{2}{|c|}{ C.C.T.H ** } \\
\cline { 3 - 8 } & & $\boldsymbol{F}$ & $\%$ & $\boldsymbol{F}$ & $\%$ \\
\hline Center & 25 & 20 & 13 & 10.23 & 12 & 9.44 \\
\hline North & 25 & 20 & 12 & 9.44 & 13 & 10.23 \\
\hline East & 18 & 14 & 16 & 12.29 & 2 & 1.57 \\
\hline West & 19 & 15 & 10 & 7.87 & 9 & 7.08 \\
\hline South & 40 & 31 & 30 & 23.62 & 10 & 7.87 \\
\hline Total & 127 & 100 & 81 & 63.77 & 46 & 36.22 \\
\hline
\end{tabular}

*W.T.H: Walffer Teaching Hospital (Medical City)

**Central Child Teaching Hospital
In the study group, forty children had swollen lymph node, 15 fatigue and weakness, 12 complaining from recurrent infection, 10 had easy bruising, 30 bone and joint pain (Table5).

Table 5: Chief compliants for (127) patient with ALL

\begin{tabular}{|l|c|c|}
\hline \multicolumn{1}{|c|}{ Categories } & $\boldsymbol{F}$ & $\%$ \\
\hline Swollen lymph node & 40 & 31 \\
\hline Fatigue and weakness & 15 & 12 \\
\hline Recurrent infection & 12 & 9 \\
\hline Easy bruising & 10 & 8 \\
\hline Bone and joint pain & 30 & 24 \\
\hline Abdominal pain & 20 & 16 \\
\hline Total & 127 & 100 \\
\hline
\end{tabular}

RESULTS

In our own study, lesions of the mucositis type were observed in ALL children in the period from 48 hours to 6 months, having various intensity and with periods without pathological lesions, which was related to the intensity of the chemotherapy. Mucosa opacity followed by redness usually occurred within 2-4 days from the treatment by (etopside, cytosar, zofran) (Table 6).

Table 6: Therapy 2 weeks (14 days)

\begin{tabular}{|c|c|c|c|c|c|c|c|c|c|c|}
\hline \multirow{2}{*}{ days } & \multicolumn{7}{|c|}{ grade } \\
\hline & $\mathbf{0}$ & & $\boldsymbol{I}$ & & 2 & & $\boldsymbol{J}$ & & 4 & \\
\hline & $\boldsymbol{F}$ & $\%$ & $\boldsymbol{F}$ & $\%$ & $\boldsymbol{F}$ & $\%$ & $\boldsymbol{F}$ & $\%$ & $\boldsymbol{F}$ & $\%$ \\
\hline 1 & $\mathrm{H}$ & 0 & 0 & 0 & 0 & 0 & 0 & 0 & 0 & 0 \\
\hline 2 & 0 & 0 & 5 & 4 & 0 & 0 & 0 & 0 & 0 & 0 \\
\hline 3 & 0 & 0 & 5 & 4 & 0 & 0 & 0 & 0 & 0 & 0 \\
\hline 4 & 0 & 0 & 3 & 2.5 & 0 & 0 & 0 & 0 & 0 & 0 \\
\hline 5 & 0 & 0 & 0 & 0 & $\mathrm{~J}$ & 2.5 & 0 & 0 & 0 & 0 \\
\hline 6 & 0 & 0 & 0 & 0 & 3 & 2.5 & 0 & 0 & 0 & 0 \\
\hline 7 & 0 & 0 & 0 & 0 & 0 & 0 & 6 & 5 & 0 & 0 \\
\hline 8 & 0 & 0 & 0 & 0 & 0 & 0 & 0 & 0 & 20 & 15.5 \\
\hline 9 & 0 & 0 & 0 & 0 & 0 & 0 & 0 & 0 & 30 & 24 \\
\hline 10 & 0 & 0 & 0 & 0 & 0 & 0 & 0 & 0 & 30 & 24 \\
\hline 11 & 0 & 0 & 0 & 0 & 0 & 0 & 0 & 0 & 22 & 16.5 \\
\hline 12 & 0 & 0 & 0 & 0 & 0 & 0 & 0 & 0 & 0 & 0 \\
\hline 13 & 0 & 0 & 0 & 0 & 0 & 0 & 0 & 0 & 0 & 0 \\
\hline 14 & 0 & 0 & 0 & 0 & 0 & 0 & 0 & 0 & 0 & 0 \\
\hline
\end{tabular}




\section{Oral Diagnosis}

The most severe lesions of the oral mucosa were observed after the first month of chemotherapy. Wounds and ulcers difficult to heal were related to blood parameters. It was observed that healing was faster, especially with regard to oral mucosa ulceration, when blood morphological parameters were improved. Lesions of the mucositis type were also dependent on the level of neutropenia. Each child with neutropenia also had fungal complications in the oral mucosa weeks from the implementation of treatment, and were mostly dependent on blood morphology and haematological therapy, as well as on the oral cavity hygiene prior to treatment. Lesions in oral mucosa were the most persistent in children with bone marrow aplasia (up to 3 weeks) and in children with neutropenia. Difficult healing was also observed following chemotherapy infusion.

\section{DISCUSSION}

Severe type of oral mucositis may be the cause of antitumor treatment postponement or modification, which results in decreased effect of the therapy $(5,6)$. Most frequently, changes of the mucositis type are observed 2-4 days after administration of chemotherapy. Lesions usually develop on buccal and tongue mucosa, as well as on the lips. The average time of development of mucositis-like lesions and ulcers was about 10-16 days of chemotherapy.

Problems in the oral cavity occurred independently of the chemotherapy protocol $(7,8)$. Patients with aplasia or neutropenia are especially exposed to dangerous fungal complications. Therefore, introduction of antifungal prevention in the form of $100 \mathrm{mg}$ of fluconazole daily may significantly reduce occurrence of pathological changes $(9,10)$. Proper function of bone marrow and improvement in blood morphology parameters lead to regression of changes in the oral mucosa ${ }^{(11)}$.

According to Karolewska et al. (2004, 2008), problems of the oral mucositis type in children with leukaemia are related to a great extent to a reduced level of S-lgA, myeloperoxidase, salivary peroxidase and to almost half the level of the total protein in saliva in comparison to patients with acute leukaemia without symptoms of oral mucositis (12, 13). The intensity of oral inflammation significantly depends on oral hygiene, which was confirmed by McGaw et al. (1985), who observed less intense and shorter symptoms of oral mucositis in subjects using mouthwash with chlorhexidine ${ }^{(14)}$. Studies conducted by Hameralak(2004) indicate a correlation between development of oral mucositis following intensive cytostatic treatment with alkaline increase in saliva $\mathrm{pH}$ in children with leukaemia. Irrigation of the oral cavity during chemotherapy with solution compatible with the saliva $\mathrm{Ph}$ of the child resulted in a reduced intensity of inflammatorynecrotic changes (15). The authors, who had observed poor oral hygiene in children prior to bone marrow transplantation, included the patients in routine dental care in order to minimise the occurrence of complications and infections in the oral cavity. The procedure included teaching the children to brush their teeth and to clean them with dental floss, as well as fluoride varnish ${ }^{(16,}$ 17).

An important problem related to oral mucositis is pain, which leads to poor nourishment and insufficient hydration of the patients and increases the risk of local infections, especially systemic ones, which may pose a threat to life. Complications in the oral cavity may also prolong treatment and increase its cost $(18,19,20)$.

Among preparations able to decompose dental plaque and prevent development of a new one, chlorhexidine seems to be the mosteffective. Numerous authors confirm chlorhexidine efficacy in $0.1 \%$ or $0.12 \%$ solution in the treatment of oral inflammatory conditions $(3,7,8,14,21)$. Certain researchers, however, do not recommend chlorhexidine preparations for children, claiming that mouthwashes containing fluoride compounds or saline have comparable therapeutic effects. Especially chlorhexidine solutions $0.2 \%$ or $0.3 \%$ are not recommended for children with acute lymphoblastic leukaemia, due to their flavour and tendency to discoloration. According to some researchers, both chlorhexidine and benzydamine have a positive effect on reduction of oral mucositis during chemotherapy, but only in children over 6 years of age ${ }^{(22,23,24)}$.

All physicians agree that the most important factor lowering the risk of oral complications is regular, at least twice a day, brushing of teeth, mouth washing and effective motivation of the patient to clean dental surfaces and oral tissues of the oral cavity. Some studies recommend that during chemotherapy, the toothbrush should be placed in a $2 \%$ chlorhexidine solution after each use, and thoroughly rinsed prior to

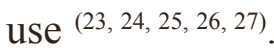

In conclusion: local treatment of oral mucositis with a polyantibiotic and antifungal mixture supported by antifungal general treatment and improvement in blood morphology in children suffering from acute lymphoblastic leukaemia improves the condition of the oral mucosa. 


\section{REFERENCES}

1. Bellield PM. Dwyer AA. Oral complications of childhood cancer and its treatment: current best practice. Eur .1 Cancer 2004: 40: 1035-41.

2. Sonis ST. Mucositis as a biological process: a newhypothesis for the development of chemotherapy-induced stomatotoxicity. Oral Oncol 1998:34:39-43.

3. Carl W, Oral complications of local and systemic cancer treatment. Curr Opin Oncol 1995:7:320-4.

4. Sonis AL. Waber DP. Sallan S. Tarbell NJ. The oral health of long-term survivors of acute lymphoblastic lekaemia: a comparison of three treatment modalites. Oral Oncol Eur J Cancer 1995: 31 B: 250-2.

5. Olczak-Kowalczyk D. Daszkiewicz M. AdamowiczKlepalska B. Mielnik- Blaszezak M. Dembowska-Bagihska B. Perek D. Stan uzebienia i higiena jamy uslnej u dzieci po przebytcj terapii przeciwnowotworowej. Ann Acad Med Gedan 2004: 34: 237-55.

6. Olczak-Kowalczyk D. Daszkiewicz M. Daszkiewicz P. Kowalczyk W. Baginska-Dembowska B. Perek D. Wybrane problem stomatologiczne pacjentw poddanych terapii przeciwnowotworowej na podstawie klasyfikacji CTCAE v3.0. Stomatol Wspkz 2007; 14 (suppl 1):20-7.

7. de Brito Costa EMM. Eernandes MZ. Quindere LB. de Souza LB. Pinto LP. Evaluation of an oral preventive protocol in children with acute lymphoblastic leukemia. Pesqui Odontol Bras 2003: 17: 147-50.

8. Pereira Pinto L. de Souza LB. Gordh-Nh ez MA. Soares RC. de Brito Costa EM. de Aquino AR. Fernandes MZ. Prevention of oral lesions in children with acute lymphoblastic leukemia. Int J Pediatr Otorhinolaryngol 2006:70: 1847-51.

9. Nicolatou-Galitis O. Athanassiadou P, Kouloulias V. et al. Herpes simplex virus-1 (HSV-1) infection in radiationinduced oral mucositis. Support Care Cancer 2006: 14: 753-62.

10. Epstein .IB. Pansier A. Lunn R. Chin E. Jacobson .1.1. Le N. Reece D. Prophylaxis of candidiasis in patients with leukemia and bone marrow transplants. Oral Surg Oral Med Oral Pathol Oral Radiol Endod 1996: 81:291-6.

11. Wisniewska .J. Tyczyiiska U. Stan uzebienia dzieci chorych na ostra. bialaczke limfoblastyczna.. Czas Stomatol 1992: 45: 393-6.

12. Karolewska E, Kozlowski Z. Konopka T. MendakM. Zmiany na blonie sluzowej jamy ustnej wprzebiegu bialaczek u dzieci - obraz kliniczny. Dent Med Probl 2004: 41: 675-81.

13. Karolewska E. Konopka T. Pupek M. Chybicka A, Mendak M. Antibacterial potential of saliva in children with leukemia. Oral Surg Oral Med Oral Pathol Oral Radiol Endod 2008: 105: 739-44.

14. McGaw WT. Belch A. Oral complications of acute leukemia: prophylactic impact of a chlorhexidine mouth rinse regimen. Oral Surg Oral Med Oral Pathol 1985: 60: 275-80.

15. HamerlakZ. Banach .J. Wyniki leczenia ciejzkich zapalen jamy uslnej u dzieci chorych na ostre bialaczki i chloniaki zlosliwe. Dent Med Probl 2004:41:687-94.

16. Lalla RV. Peterson DE. Oral mucositis. Dent Clin N Am 2005: 49: 167-84.

17. Vaughan MD. Rowland CC. long X. Srivastava DK. Hale GA. Rochester R. Kaste SC. Dental abnormalities in children preparing for pediatric bone marrow transplantation. Bone Marrow Transplant 2005:36:863-66.

18. Sonis ST. Elting LS. Keefe D. Peterson DE. Schubert M. Hauer-Jensen M. Bekele BN. Raber-Durlacher J, Donnelly JP. Rubenstein EB: Mucositis Study Section of the Multinational Association for Supportive Care in Cancer: International Society for Oral Oncology. Perspectives on cancer therapy-induced mucosal injury: pathogenesis measurement, epidemiology, and consequences for patients. Cancer 2004: 100 (9 Suppl.): 1995-2025.

19. Epstein JB. Schubert MM. Managing pain in mucositis. Semin Oncol Nurs 2004: 20: 30-7.

20. Peterson DE. New strategies for oral mucositis management in cancer patients. J Support Oncol 2006: 4 (2 suppl. 1): 9-13.

21. Mielnik-Blaszczak M. Stanios-Sniezynska J. Zastosowanie $0.2 \%$ glukonianu chlorheksydyny w proftlaktyce prchnicy u dzieci. Mag Stomatol 2001: 11:26-9

22. Scully C, Sonis S. Diz PD. Oral mucositis. Oral Dis 2006: 12:229-41.

23. Cheng KK. Chang AM. Yuen MP. Prevention of oral mucositis in paediatric patients treated with chemotherapy: arandomised crossover trial comparing two protocols of oral care. Eur .1 Cancer 2004: 40: 1208-16.

24. Pitten FA. Kiefer T. Buth C. Doelken G. Kramer A. Do cancer patients with chemotherapy-induced leukopenia benefit from an antiseptic chlorhexidine-based oral rinse? A double-blind, block-randomized, controlled study. J Hosp Infect 2003: 53: 283-91.

25. Bonnaure-Mallet M, Bunetel L, Tricot-Doleux S. Guerin J, Bergeron C, LeGall E. Oral complications during treatment of malignant diseases in childhood: effects of tooth brushing. Eur J Cancer 1998: 34: 1588-91.

26. van der Rijt CCD. van Zuijlen L. Studies on supportive care in oral mucositis: random or randomised? Eur .1 Cancer 2001; 37: 1971-5.

27. Konopka T. Mendrela E. Norowska M. Kozlowski Z. Chaber R. To porski J. Zmiany w jamie ustnej w przebiegu bialaczek u dzieci. Czas Stomatol 2001: 54: 217-25. 